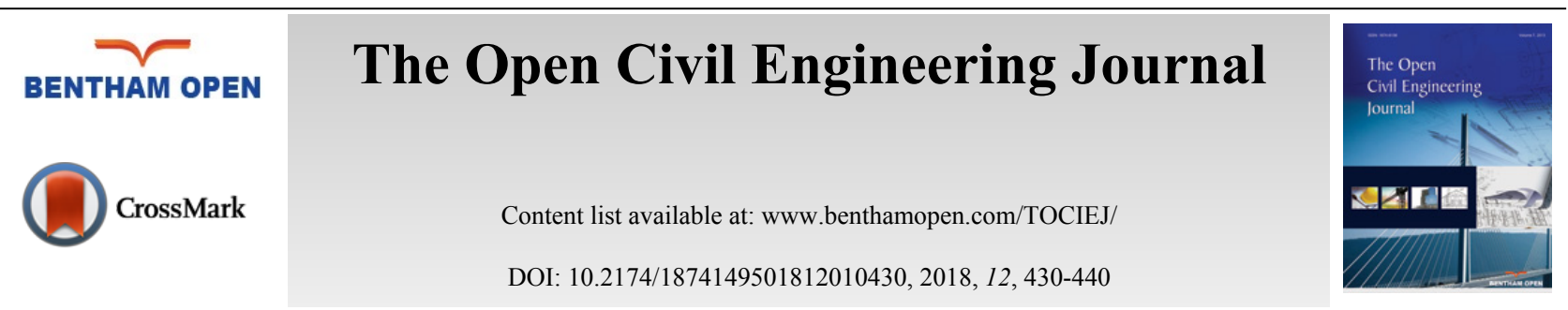

RESEARCH ARTICLE

\title{
Experimental Study on the Effects of Recycled Concrete Powder on Properties of Self-Compacting Concrete
}

\author{
Hongzhu Quan ${ }^{1, *}$ and Hideo Kasami ${ }^{2}$

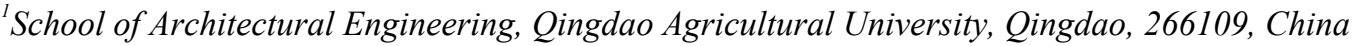 \\ ${ }^{2}$ Japan Association for Building Research Promotion, Tokyo, 108-0014, Japan
}

Received: August 4, 2018

Revised: October 25, 2018

Accepted: November 3, 2018

\begin{abstract}
:
Introduction:

Although hundreds million tons of concrete wastes have been generated annually in China, the use of recycled aggregate for concrete is limited because of low density and high absorption due to adhered cement paste and mortar.
\end{abstract}

\section{Methods:}

A new method to produce high quality recycled aggregate by heating and grinding concrete rubbles to separate cement portions adhering to aggregate was developed recently. In this process by-product powder with the fineness of $400 \mathrm{~m}^{2} / \mathrm{kg}$ is generated. Byproduct recycled fine powder consists of fine particles of hydrated cement and crushed aggregate. To use the recycled fine powder as concrete additives two series of experiments were performed to make clear of the effect of recycled fine powder.

\section{Results and Conclusion:}

Self-compacting concrete with recycled fine powder, granulated blast furnace slag and granulated limestone were tested for slump flow, compressive strength, modulus of elasticity and drying shrinkage. Reduction in super plasticizing effect of high range water reducer was found for concrete with recycled powder. Compressive strength of concrete with recycled fine powder was the same as those with granulated limestone, and lower than those with granulated blast furnace slag. Concrete with recycled fine powder showed lower elastic modulus and higher drying shrinkage than those with granulated blast furnace slag and granulated limestone. The recycled fine powder is usable for self-compacting concrete without further processing, despite the possible increase in dosage of high range water reducer for a given slump flow and in drying shrinkage. The addition of granulated blast furnace slag together with recycled powder to self-compacting concrete improved super plasticizing effect of high range water reducer and properties of concrete.

Keywords: Recycled concrete powder, Self-compacting concrete, Compressive strength, Modulus of elasticity, Drying shrinkage, Granulated blast.

\section{INTRODUCTION}

Although hundreds million tons of concrete wastes have been generated annually in China [1 - 2], the use of recycled aggregate for concrete is limited because of low density and high absorption due to adhered cement paste and mortar [3 - 5]. A new method for producing high quality recycled aggregate by heating and grinding method, in which concrete rubbles are ground after heating at $300^{\circ} \mathrm{C}$ in order to remove cement portion adhering to aggregate, has been developed recently [6-11]. By-product powder with a specific surface of $400 \mathrm{~m}^{2} / \mathrm{kg}$ to $800 \mathrm{~m}^{2} / \mathrm{kg}$ is generated in the heating and grinding process, and the percentage is $20 \%$ to $30 \%$ by weight of concrete [12-13]. The by-product

* Address Correspondence to this author at the School of Architectural Engineering, Qingdao Agricultural University, Qingdao, 266109, China, Tel: +86-532-88030411 Off: +86-13792443322, Fax: +86-532-88030411, E-mail:1162944058@qq.com. 
recycled fine powder is usable as material for Portland cement. However, it is not easy to consume in cement industry all of the yield to be generated when the method is put into practice [14]. The use of recycled fine powder as mineral additives for conventional concrete increases water content and drying shrinkage of conventional concrete, and reduces the effect of high range water reducer and increases viscosity of flowing concrete with high reducer and increases viscosity of flowing concrete with high range water reducer [15 - 17]. Considering the characteristics of recycled fine powder, it might be usable for self-compacting concrete to prevent segregation with-out further processing, if it does not cause negative effects on concrete qualities [18 - 21].

To clarify the influence of recycled fine powder for self-compacting concrete containing high range water reducer of a water soluble methacrylic graft polymers, two series of experimental studies were carried out. The heating and grinding method, concrete rubbles are crushed to reduce particle size under $50 \mathrm{~mm}$. Then, they are heated at $300^{\circ} \mathrm{C}$ with hot blast in order to make the adhered cement paste and mortar brittle, and the rubbles are ground in tube mills to remove adhered cement paste and mortar from aggregate particles. The percentage of recycled aggregate with respect to the original concrete is over $70 \%$ by weight, and the amount of by-product recycled fine powder generated in the grinding process is estimated to be $25 \%$ to $30 \%$ by weight of concrete.

Chemical composition and characteristics of by-product recycled fine powder are shown in Table $\mathbf{1}$ and Table 2. The recycled fine powder has a specific surface area of $330 \mathrm{~m}^{2} / \mathrm{kg}$ to $530 \mathrm{~m}^{2} / \mathrm{kg}$, and consists of particles of crushed aggregate with a size under $100 \mu \mathrm{m}$, and fine particles of calcium carbonate with a size of $1 \mu \mathrm{m}$ to $10 \mu \mathrm{m}$. The particle size distribution of recycled fine powder is shown in (Fig. 1).

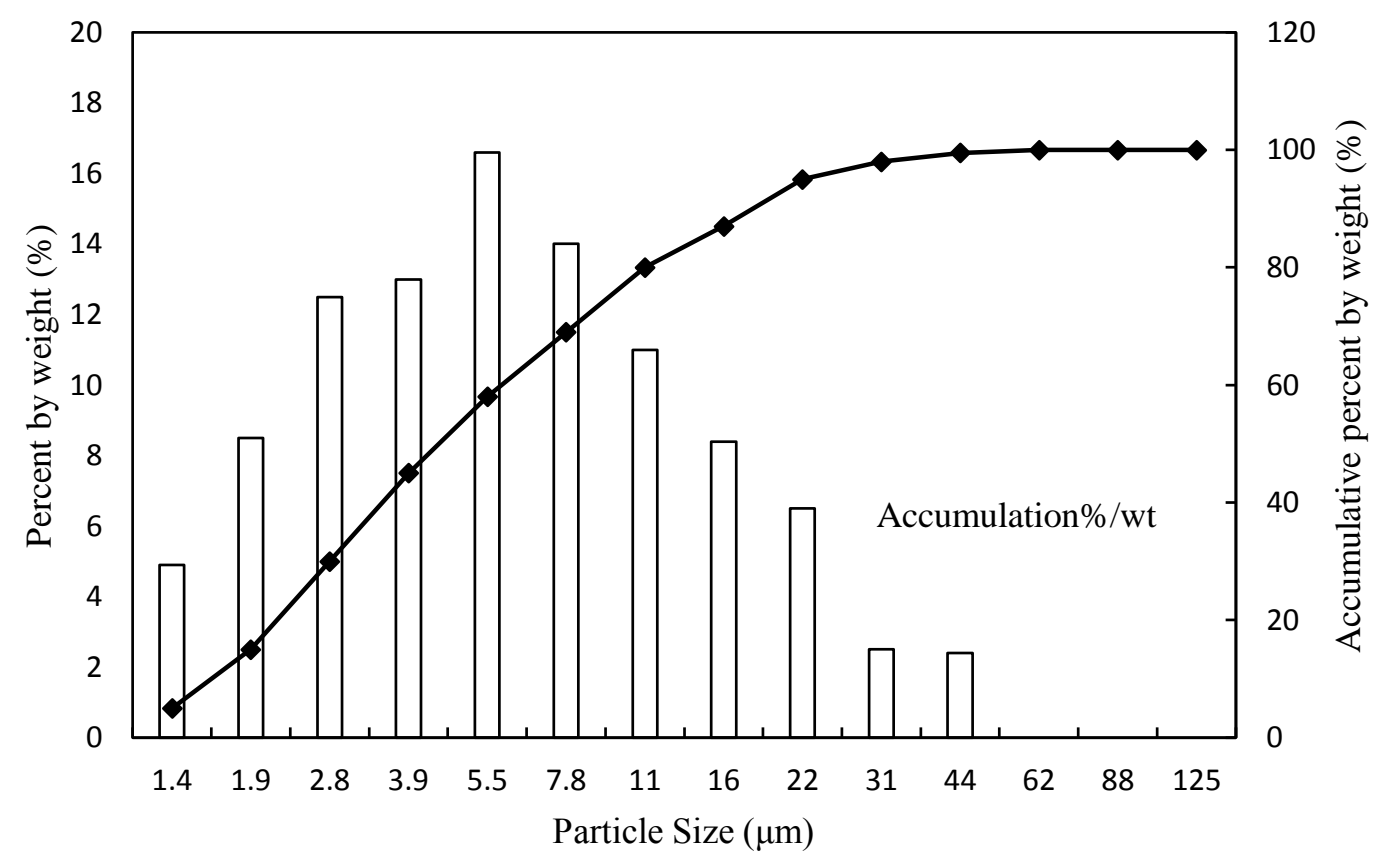

Fig. (1). Particle size distribution of recycled fine powder.

Table 1. Chemical composition of by-product recycled fine powder (\%).

\begin{tabular}{|c|c|c|c|c|c|c|c|}
\hline- & Loss Ignition & SiO2 & Al2O3 & Fe2O3 & CaO & MgO & SO3 \\
\hline RFP[1]-R & 14.4 & 42.9 & 8.7 & 2.9 & 26.7 & 1.4 & 0.7 \\
\hline RFP-A & 9.8 & 50.3 & 10.5 & 3.6 & 21.5 & 1.3 & 0.8 \\
\hline RFP-B & 7.7 & 56.5 & 14.0 & 3.3 & 15.2 & 0.8 & 0.5 \\
\hline RFP-C & 18.8 & 43.4 & 3.6 & 3.2 & 27.0 & 1.2 & 0.8 \\
\hline
\end{tabular}

[1]RFP: Recycled Fine Powder 
Table 2. Characteristics of by-product recycled fine powder.

\begin{tabular}{|c|c|c|c|c|c|c|c|c|c|}
\hline \multirow{3}{*}{$\begin{array}{l}\text { Recycled } \\
\text { Concrete } \\
\text { Powder }\end{array}$} & \multicolumn{7}{|c|}{ Original Concrete for Recycling } & \multicolumn{2}{|c|}{ Recycled Concrete Powder } \\
\hline & \multicolumn{3}{|c|}{ Material Used } & \multicolumn{2}{|c|}{ Mixture Proportion } & \multirow{2}{*}{$\begin{array}{c}\text { Age at } \\
\text { Recycling } \\
\text { (month) }\end{array}$} & \multirow{2}{*}{$\begin{array}{c}\text { Compressive } \\
\text { Strength } \\
\text { (MPa) }\end{array}$} & \multirow{2}{*}{$\begin{array}{l}\text { Specific } \\
\text { Gravity } \\
\left(\mathrm{kg} / \mathrm{m}^{3}\right)\end{array}$} & \multirow{2}{*}{$\begin{array}{c}\text { Specific } \\
\text { Surface } \\
\text { Area } \\
\left(\mathrm{m}^{2} / \mathrm{kg}\right)\end{array}$} \\
\hline & Type of Cement & $\begin{array}{c}\text { Coarse } \\
\text { Aggregate }\end{array}$ & $\begin{array}{c}\text { Fine } \\
\text { Aggregate }\end{array}$ & $\mathbf{w} / \mathbf{c}$ & $\begin{array}{l}\text { Cement } \\
\left(\mathrm{kg} / \mathrm{m}^{3}\right)\end{array}$ & & & & \\
\hline RFP-R & $\begin{array}{c}\text { Portland } \\
\text { Fly ash }\end{array}$ & Gravel & River Sand & 0.52 & 308 & 6 & Unknown & 2420 & 395 \\
\hline RFP-A & $\begin{array}{l}\text { Normal } \\
\text { Portland }\end{array}$ & $\begin{array}{l}\text { Crushed } \\
\text { Stone }\end{array}$ & River Sand & 0.50 & 314 & 6 & 52.0 & 2370 & 532 \\
\hline RFP-B & $\begin{array}{l}\text { Portland } \\
\text { Fly ash }\end{array}$ & Gravel & River Sand & Unknown & Unknown & 360 & 35.7 & 2520 & 369 \\
\hline RFP-C & Unknown & Gravel & River Sand & Unknown & Unknown & 360 & Unknown & 2350 & 330 \\
\hline
\end{tabular}

\section{EXPERIMENT}

\subsection{Scope of Experiment}

The recycled fine powder obtained in the production of high quality recycled aggregate by the heating and grinding method increases viscosity and water requirement when it is used as mineral additives for conventional concrete, due to its high specific surface area and angular particle shape. However, it is useful as mineral additives for high performance concrete, or self-compacting concrete, to enhance viscosity. Self-compacting concrete, is a high performance concrete with a slump flow of $500 \mathrm{~mm}$ to $700 \mathrm{~mm}$ without segregation, usually containing high range water reducer and mineral additives.

In order to utilize the recycled fine powder for self-compacting concrete, two series of experiments were carried out. The objective of the series 1 experiment is to make clear of the effects of recycled fine powder on the properties of selfcompacting concrete. The objective of the series 2 experiment is to investigate the effect of recycled fine powder on the super plasticizing effect of high range water reducer and slump flow of self-compacting concrete.

\subsection{Material Used}

Cement: Three brands of normal Portland cement in equal parts were used, and the average specific gravity was $3.16 \mathrm{~g} / \mathrm{cm}^{3}$ and specific surface area was $335 \mathrm{~m}^{2} / \mathrm{kg}$. The characteristics of cement used are given in Table 3 .

Table 3. Characteristics of cement used.

\begin{tabular}{|c|c|c|c|c|c|c|c|c|c|}
\hline \multirow{2}{*}{ Notation } & \multirow{2}{*}{$\begin{array}{l}\text { Density } \\
\left(\mathrm{g} / \mathrm{cm}^{3}\right)\end{array}$} & \multirow{2}{*}{$\begin{array}{c}\text { Specific Surface } \\
\text { Area } \\
\left(\mathbf{m}^{2} / \mathbf{k g}\right)\end{array}$} & \multirow{2}{*}{$\begin{array}{l}\text { Ig Loss } \\
(\%)\end{array}$} & \multirow{2}{*}{$\begin{array}{l}\text { C3S } \\
(\%)\end{array}$} & \multirow{2}{*}{$\begin{array}{l}\mathrm{C} 2 \mathrm{~S} \\
(\%)\end{array}$} & \multirow{2}{*}{$\begin{array}{l}\text { C3A } \\
(\%)\end{array}$} & \multicolumn{3}{|c|}{$\begin{array}{c}\text { Compressive Strength } \\
\left(\mathrm{N} / \mathbf{m m}^{2}\right)\end{array}$} \\
\hline & & & & & & & 3 days & 7 days & 28 days \\
\hline NP & 3.16 & 335 & 2.16 & 55.5 & 19.0 & 9.0 & 30.3 & 45.8 & 62.2 \\
\hline
\end{tabular}

Aggregate: The coarse aggregate used was crushed sand stone. The fine aggregate used was river sand. Physical properties of aggregates used are given in Table 4.

Mineral additives: In the series 1, a recycled fine powder, a ground blast furnace slag and a ground limestone were used as additives for self-compacting concrete. RFP-R, the recycled fine powder used, was obtained as by-products in the recycling of a concrete made of Portland fly ash cement, river gravel and sand, and the age of recycling was 6 month. Specific gravity was $2.42 \mathrm{~g} / \mathrm{cm}^{3}$ and specific surface area was $395 \mathrm{~m}^{2} / \mathrm{kg}$, as shown in Tables $\mathbf{1}$ and 2 . The ground blast furnace slag used had specific gravity of $2.89 \mathrm{~g} / \mathrm{cm}^{3}$ and specific surface area of $412 \mathrm{~m}^{2} / \mathrm{kg}$. The ground limestone used had a specific gravity of $2.70 \mathrm{~g} / \mathrm{cm}^{3}$ and specific surface area of $500 \mathrm{~m}^{2} / \mathrm{kg}$. In the series 2 , three types of recycled powders, RFP-A, RFP-B and RFP-C, were used for self-compacting concrete. The same ground blast furnace slag and ground limestone as those in the series 1 were also used for self-compacting concrete. Characteristics and chemical composition of the recycled powders are shown in Table $\mathbf{1}$ and Table $\mathbf{2}$. The recycled fine powder RFP-A, obtained from a concrete made of normal Portland cement, crushed stone and river sand at the age of $6 \mathrm{months}$, had a specific gravity of $2.37 \mathrm{~g} / \mathrm{cm}^{3}$ and specific surface area of $532 \mathrm{~m}^{2} / \mathrm{kg}$. RFP-B and RFP-C were obtained from demolished concretes at the age of 30 years. RFP-B had a specific surface area $369 \mathrm{~m}^{2} / \mathrm{kg}$, and RFP-C had a specific surface area of $330 \mathrm{~m}^{2} / \mathrm{kg}$.

Chemical admixture: An air entraining water reducer was used for conventional concrete. The high range water 
reducer used for self-compacting concrete was a water soluble methacrylic graft polymers, having carboxylic groups and sulfonic groups as anion groups as well as polyoxylene groups as side chains in their molecules.

Table 4. Physical properties of aggregates used.

\begin{tabular}{|c|c|c|c|c|c|}
\hline Type of Aggregate & $\begin{array}{c}\text { Maximum Size } \\
(\mathbf{m m})\end{array}$ & $\begin{array}{c}\text { Specific Gravity } \\
\left(\mathbf{k g} / \mathbf{m}^{\mathbf{3}}\right)\end{array}$ & $\begin{array}{c}\text { Absorption } \\
(\mathbf{\%})\end{array}$ & $\begin{array}{c}\text { Bulk Density } \\
\left(\mathbf{k g} / \mathbf{m}^{\mathbf{3}}\right)\end{array}$ & Fineness Modulus \\
\hline Crushed Sand Stone & 20 & 2660 & 0.82 & 1590 & 6.63 \\
\hline River Sand & 5 & 2610 & 1.28 & 1800 & 3.05 \\
\hline
\end{tabular}

\subsection{Mixture Proportions}

Series 1: The mixture proportions of conventional concrete and self-compacting concrete are given in Table 5. The target slump of conventional concrete was $180 \mathrm{~mm}$, and the target slump flow of self-compacting concretes was $650 \mathrm{~mm}$. The W/C was 0.50 for self-compacting concretes with ground blast furnace slag and ground limestone, and for conventional concrete. The W/C of self-compacting concretes with recycled fine powder were 0.50 and 0.60.

Table 5. Mixture proportion of concrete (Series 1).

\begin{tabular}{|c|c|c|c|c|c|c|c|c|c|}
\hline \multirow[b]{2}{*}{ Mixture } & \multirow{2}{*}{$\begin{array}{l}\text { Mineral } \\
\text { Additives }\end{array}$} & \multirow[b]{2}{*}{$\mathbf{W} / \mathbf{C}$} & \multirow{2}{*}{$\begin{array}{l}\text { W/CM Ratio } \\
\text { by Weight }\end{array}$} & \multirow{2}{*}{$\begin{array}{l}\text { W/CM Ratio } \\
\text { by Volume }\end{array}$} & \multicolumn{5}{|c|}{ Weight $\left(\mathrm{kg} / \mathrm{m}^{3}\right)$} \\
\hline & & & & & Water & Cement & \begin{tabular}{|l|} 
Mineral \\
Additive
\end{tabular} & \begin{tabular}{|c|} 
Fine \\
Aggregate
\end{tabular} & \begin{tabular}{|c|} 
Coarse \\
Aggregate
\end{tabular} \\
\hline C-50 & - & \begin{tabular}{|l|}
0.50 \\
\end{tabular} & - & - & 180 & 360 & \begin{tabular}{|l|}
- \\
\end{tabular} & \begin{tabular}{|l|}
797 \\
\end{tabular} & 962 \\
\hline HB-50 & Ground Slag & 0.50 & 0.33 & 1.00 & 180 & 360 & 191 & 774 & 850 \\
\hline HL-50 & Ground Limestone & 0.50 & 0.33 & 1.00 & 180 & 360 & 178 & 774 & 850 \\
\hline HR-50 & \multirow{2}{*}{ Recycled powder } & 0.50 & 0.38 & 1.10 & 180 & 360 & 120 & 816 & 850 \\
\hline HR-60 & & 0.60 & 0.42 & 1.20 & 180 & 300 & 133 & 853 & 850 \\
\hline
\end{tabular}

Series 2: Mixture proportions in volume of self-compacting concretes with recycled fine powder in volume were the same as those with ground slag and ground limestone, as shown in Table 6. Dosage of high range water reducer(HRWR) by the percentage of cementitious material including mineral additives was varied from $0.55 \%$ to $0.825 \%$ for self-compacting concrete with ground slag and ground limestone, and $1.125 \%$ to $2.5 \%$ for the concrete with recycled fine powder.

Table 6. Mixture proportion of concrete (Series 2).

\begin{tabular}{|c|c|c|c|c|c|c|c|c|c|}
\hline \multirow{2}{*}{ Mixture } & $\begin{array}{c}\text { Mineral } \\
\text { Additives }\end{array}$ & W/C & \multirow{2}{*}{$\begin{array}{c}\text { W/CM Ratio } \\
\text { By Weight }\end{array}$} & \multicolumn{2}{|c|}{$\begin{array}{c}\text { W/CM Ratio } \\
\text { By Volume }\end{array}$} & Water & Cement & Mineral \\
Additive & $\begin{array}{c}\text { Fine } \\
\text { Aggregate }\end{array}$ & $\begin{array}{c}\text { Coarse } \\
\text { Aggregate }\end{array}$ \\
\hline C-50 & - & 0.50 & - & - & 183 & 366 & - & 784 & 962 \\
\hline HB-50 & Ground Slag & 0.50 & 0.33 & 1.00 & 183 & 366 & 194 & 784 & 850 \\
\hline HL-50 & Ground Limestone & 0.50 & 0.34 & 1.00 & 183 & 366 & 181 & 784 & 850 \\
\hline HR-50A & Recycled powder A & 0.50 & 0.34 & 1.00 & 183 & 366 & 169 & 784 & 850 \\
\hline HR-50B & Recycled powder B & 0.50 & 0.35 & 1.00 & 183 & 366 & 159 & 784 & 850 \\
\hline HR-50C & Recycled powder C & 0.50 & 0.35 & 1.00 & 183 & 366 & 157 & 784 & 850 \\
\hline HRB-50A & $\begin{array}{c}\text { Recycled powder A } \\
\text { Ground Slag }\end{array}$ & 0.50 & 0.34 & 1.00 & 183 & 366 & 84 & 784 & 850 \\
\hline
\end{tabular}

\subsection{Experimental Procedures}

Series 1: The concrete was mixed in a 50 litre pan type mixer. The target temperature of fresh concrete was $20^{\circ} \mathrm{C}$. Cement, mineral additives, sand and water containing chemical admixture were fed to the mixer. To adjust the water absorption of recycled fine powder, the amount of water was increased by $5 \%$ in weight of recycled fine powder estimating water absorption in concrete mix to be about 5\%. After mixing mortar for 90 seconds, coarse aggregate was fed to the mixer and mixing was performed for 90 seconds. Concretes were tested for slump, slump flow, air content, compressive strength, modulus of elasticity and drying shrinkage.

The specimens for compressive strength using $100 \times 200 \mathrm{~mm}$ cylinders were cured in water at $20^{\circ} \mathrm{C}$ and tested at 7 days and 28 days (JIS A $1108-2006$ ). $100 \times 100 \times 400 \mathrm{~mm}$ prism specimens for drying shrinkage test were cured in water until the age of 7 days and were kept at $20^{\circ} \mathrm{C}$ and relative humidity of $60 \%$ and were tested for length change for 91 
days (JIS A 1129-1-2010).

Series 2: The concrete was mixed with the same mixer as that for series 1, but the mixing procedure was changed. Cement, mineral additives, sand and one half of the amount of water were fed to the mixer. The amount of mixing water was increased by $5 \%$ of recycled fine powder to adjust water absorption. After 60 second's mixing, the mixer was stopped for 60 seconds to ensure that the recycled fine powder is sufficiently wetted. Then, the remainder of water containing high range water reducer were fed to the mixer. The mixing was continued for 60 seconds, then the coarse aggregate was added to the mixer, and the whole mixture was mixed for 60 seconds. Concretes were tested for slump flow, flow speed, air content, compressive and splitting tensile strengths, modulus of elasticity and drying shrinkage, with the same methods as in the series 1 . The specimens for splitting tensile strength using $100 \times 200 \mathrm{~mm}$ cylinders were cured in water at $20^{\circ} \mathrm{C}$ and tested at 28 days (JIS A 1113-2006).

\section{TEST RESULTS AND DISCUSSION}

\subsection{Results of Series 1 Experiment}

Table 7 shows test results of fresh and hardened concrete of Series 1 Experiment. Higher dosage of high range water reducer was required for self-compacting concrete with recycled fine powder for a given slump flow than those with ground blast furnace slag and ground limestone. And self-compacting concrete with recycled fine powder was found to be less workable than those with ground slag and ground limestone. Flow speed of self-compacting concrete with recycled fine powder was much slower than those with ground slag and ground limestone of the same slump flow.

Table 7. Test results of fresh and Hardened Concrete (Series 1).

\begin{tabular}{|c|c|c|c|c|c|c|c|c|c|c|c|}
\hline \multirow[t]{2}{*}{ Mixture } & \multirow{2}{*}{$\begin{array}{c}\text { Dosage of HRWR[1] } \\
(\mathrm{CM} \times \%)\end{array}$} & \multirow{2}{*}{$\begin{array}{l}\text { Slump } \\
(\mathrm{mm})\end{array}$} & \multirow{2}{*}{$\begin{array}{c}\text { Slump } \\
\text { Flow } \\
(\mathbf{m m})\end{array}$} & \multirow{2}{*}{$\begin{array}{c}\text { Flow } \\
\text { Speed } \\
(\mathrm{mm} / \mathrm{sec})\end{array}$} & \multicolumn{2}{|c|}{$\begin{array}{c}\text { Air Content } \\
(\%)\end{array}$} & \multicolumn{2}{|c|}{$\begin{array}{c}\text { Compressive } \\
\text { Strength } \\
\text { (MPa) }\end{array}$} & \multicolumn{2}{|c|}{$\begin{array}{l}\text { Modulus of Elasticity } \\
\text { (GPa) }\end{array}$} & \multirow{2}{*}{\begin{tabular}{|c}
$\begin{array}{c}\text { Drying } \\
\text { Shrinkage } \\
(\times 10-4)\end{array}$ \\
91 days
\end{tabular}} \\
\hline & & & & & $\begin{array}{l}\text { Pressure } \\
\text { Method }\end{array}$ & Mass Method & 7 days & 28 days & 7 days & 28 days & \\
\hline $\mathrm{C}-50$ & - & 180 & - & - & 4.9 & 5.0 & 33.4 & 41.6 & - & 25.3 & 7.34 \\
\hline HB-50 & 0.80 & - & 650 & 28.9 & 1.4 & 1.4 & 58.7 & 78.5 & - & 32.9 & 5.40 \\
\hline HL-50 & 1.00 & - & 685 & 34.1 & 1.7 & 1.6 & 47.4 & 53.3 & - & 29.9 & 6.66 \\
\hline HR-50 & 2.00 & - & 620 & 9.5 & 1.6 & 2.0 & 47.2 & 52.5 & - & 27.1 & 7.76 \\
\hline HR-60 & 2.00 & - & 595 & 8.7 & 1.9 & 2.5 & 37.3 & 42.0 & - & 24.8 & 8.21 \\
\hline
\end{tabular}

[1] Percent by the weight of cementicious materials (cement+mineral additives.

There were no difference between the air content measured by pressure method and mass method for the concrete with ground indicates that the estimation of water absorption of recycled fine powder during mixing was reasonable.

Compressive strength of self-compacting concrete with recycled fine powder was the same as those with ground lime stone, lower than those with ground slag and higher than that of conventional concrete of the same W/C or W/CM.

Modulus of elasticity was lower and drying shrinkage was greater for self-compacting concrete with recycled fine powder than those with ground slag or ground limestone.

\subsection{Results of Series 2 Experiment}

Table 8 shows test results of fresh and hardened concrete of Series 2 Experiment. Fig. (2) shows the relationship between the dosage of high range water reducer and slump flow of self-compacting concrete with recycled fine powder, ground slag and ground lime stone.

Table 8. Test results of fresh and hardened Concrete (Series2).

\begin{tabular}{|c|c|c|c|c|c|c|c|c|c|c|c|}
\hline \multirow{2}{*}{ Mixture } & \multirow{2}{*}{$\begin{array}{l}\text { Dosage of HRWR[1] } \\
(\mathrm{CM} \times \%)\end{array}$} & \multirow{2}{*}{$\begin{array}{l}\text { Slump } \\
(\mathrm{mm})\end{array}$} & \multirow{2}{*}{$\begin{array}{c}\text { Slump } \\
\text { Flow } \\
(\mathrm{mm})\end{array}$} & \multirow{2}{*}{$\begin{array}{c}\text { Flow } \\
\text { Speed } \\
(\mathrm{mm} / \mathrm{sec})\end{array}$} & \multirow{2}{*}{\begin{tabular}{|c|}
$\begin{array}{c}\text { Air-Content } \\
(\%)\end{array}$ \\
$\begin{array}{c}\text { Pressure } \\
\text { Method }\end{array}$ \\
\end{tabular}} & \multicolumn{2}{|c|}{$\begin{array}{c}\text { Compressive } \\
\text { Strength } \\
\text { (MPa) }\end{array}$} & \multirow{2}{*}{\begin{tabular}{|c|}
$\begin{array}{c}\text { Tensile } \\
\text { Strength } \\
(\mathrm{MPa})\end{array}$ \\
28 days
\end{tabular}} & \multicolumn{2}{|c|}{$\begin{array}{l}\text { Modulus of Elasticity } \\
\text { (GPa) }\end{array}$} & \multirow{2}{*}{\begin{tabular}{|c|}
$\begin{array}{c}\text { Drying } \\
\text { Shrinkage } \\
(\times 10-4)\end{array}$ \\
91 days
\end{tabular}} \\
\hline & & & & & & 7 days & 28 days & & 7 days & 28 days & \\
\hline C-50 & 0.75 & 185 & - & - & 5.1 & 36.5 & 44.7 & 3.58 & 25.0 & 27.3 & 6.54 \\
\hline HB-50 & 0.675 & - & 660 & 38.4 & 1.4 & 58.1 & 81.5 & 5.03 & 29.3 & 35.7 & 5.08 \\
\hline HL-50 & 2.125 & - & 623 & 39.6 & 1.3 & 51.9 & 60.3 & 4.23 & 30.0 & 32.6 & 6.04 \\
\hline
\end{tabular}




\begin{tabular}{|c|c|c|c|c|c|c|c|c|c|c|c|}
\hline \multirow{2}{*}{ Mixture } & \multirow{2}{*}{$\begin{array}{c}\text { Dosage of HRWR[1] } \\
(\text { CM } \times \%)\end{array}$} & \multirow{2}{*}{$\begin{array}{l}\text { Slump } \\
(\mathbf{m m})\end{array}$} & \multirow{2}{*}{$\begin{array}{c}\text { Slump } \\
\text { Flow } \\
(\mathbf{m m})\end{array}$} & \multirow{2}{*}{$\begin{array}{c}\text { Flow } \\
\text { Speed } \\
(\mathbf{m m} / \mathbf{s e c})\end{array}$} & \multirow{2}{*}{\begin{tabular}{|c|}
$\begin{array}{c}\text { Air-Content } \\
(\%)\end{array}$ \\
$\begin{array}{c}\text { Pressure } \\
\text { Method }\end{array}$ \\
\end{tabular}} & \multicolumn{2}{|c|}{$\begin{array}{c}\text { Compressive } \\
\text { Strength } \\
\text { (MPa) }\end{array}$} & \multirow{2}{*}{\begin{tabular}{|c|}
$\begin{array}{c}\text { Tensile } \\
\text { Strength } \\
\text { (MPa) }\end{array}$ \\
28 days \\
\end{tabular}} & \multicolumn{2}{|c|}{$\begin{array}{l}\text { Modulus of Elasticity } \\
\text { (GPa) }\end{array}$} & \multirow{2}{*}{\begin{tabular}{|c|}
$\begin{array}{c}\text { Drying } \\
\text { Shrinkage } \\
(\times 10-4)\end{array}$ \\
91 days
\end{tabular}} \\
\hline & & & & & & 7 days & 28 days & & 7 days & 28 days & \\
\hline HR-50A & 2.125 & - & 595 & 9.5 & 1.1 & 51.8 & 62.6 & 4.08 & 27.9 & 30.8 & 7.79 \\
\hline HR-50B & 2.125 & - & 658 & 23.9 & 2.0 & 54.0 & 64.0 & 4.40 & 28.3 & 31.0 & 7.94 \\
\hline HR-50C & 2.125 & - & 655 & 19.8 & 1.6 & 54.8 & 65.8 & 3.77 & 28.4 & 30.8 & 7.93 \\
\hline HRB-50A & 1.25 & - & 650 & 25.4 & 1.6 & 60.9 & 77.5 & 4.48 & 30.9 & 33.4 & 6.26 \\
\hline
\end{tabular}

[1] Percent by the weight of cementicious materials (cement+mineral additives)

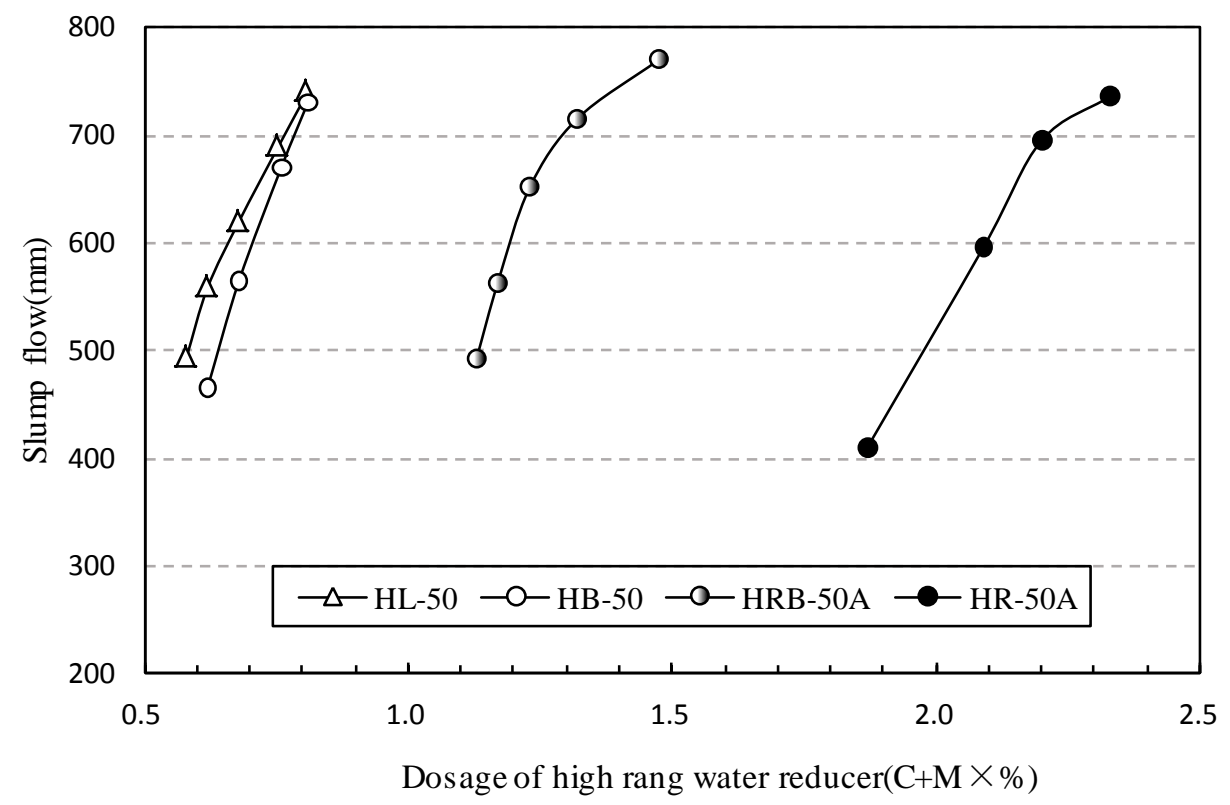

Fig. (2). Variation of the slump flow with dosage of HRWR.

Although slump flow of self-compacting concrete with recycled fine powder increased with the dosage of high range water reducer in the same manner as those with ground slag and ground limestone, super plasticizing effect of high range water reducer was reduced with the addition of recycled fine powder. Required dosage of high range water reducer for a given slump flow was 3 times as much as that with ground slag or lime stone.

However, addition of ground slag together with recycled fine powder improved super plasticizing effect of high range water reducer, and required dosage for a given slump flow was reduced to twice as much as those with ground slag and ground limestone. Self-compacting concrete with recycled fine powder was found to be less workable than those with ground slag and ground lime stone of the same slump flow. Flow speed of self-compacting concrete with recycled fine powder was slower than those with ground slag and limestone of the same slump flow. Flow speed was more affected with the quality of recycled fine powder than slump flow. Flow speed of self-compacting concrete with recycled fine powder was $9.5 \mathrm{~m} / \mathrm{sec}$ to $23.9 \mathrm{~m} / \mathrm{sec}$, while those with ground slag and ground limestone showed higher flow speed of $38.4 \mathrm{~m} / \mathrm{sec}$ to $39.8 \mathrm{~m} / \mathrm{sec}$.

Compressive strength of self-compacting concrete with recycled fine powder was higher by $30 \%$ than conventional concrete of the same W/CM and slightly greater than those of self-compacting concrete with limestone, and less than those with ground slag by $25 \%$, as shown in Fig. (3). Compressive strength of self-compacting concrete containing recycled fine powder was increased with the addition of ground slag. 


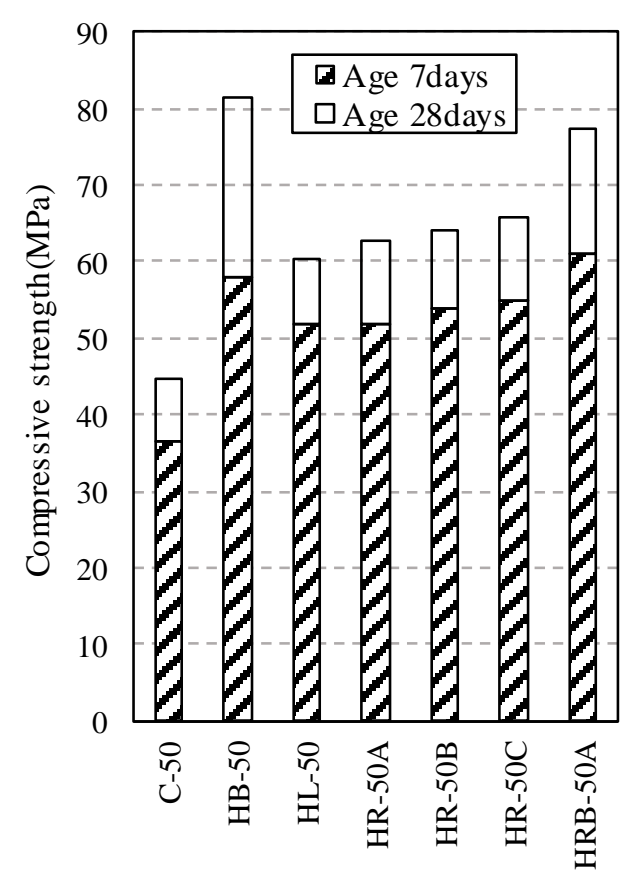

Fig. (3). Compressive strength of concrete Fig.4 Splitting tensile strength of concrete.

Splitting tensile strength of self-compacting concrete with recycled fine powder was lower than those with slag and limestone, and greater than conventional concrete, it is due to filler effect [22]. The addition of ground slag together with recycled fine powder increased splitting tensile strength with recycled fine powder, as shown in (Fig. 4).

Modulus of elasticity was found to be smaller for concrete with recycled fine powder than for those with ground slag and ground limestone as shown in Fig. (5). Addition of ground slag together with recycled fine powder also improved modulus of elasticity much the same as comnressive and snlitting tensile strengths.

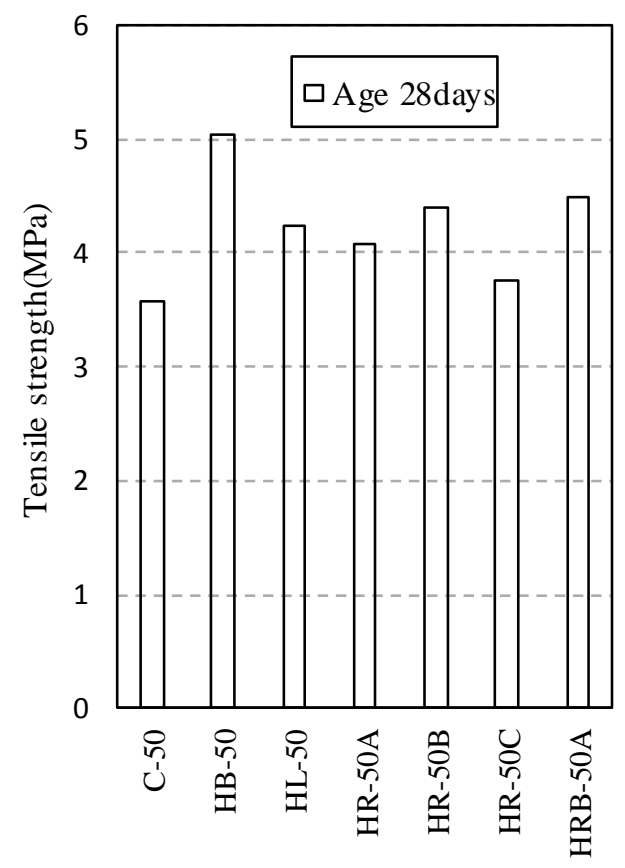

Fig. (4). Compressive strength of concrete Fig.4 Splitting tensile strength of concrete. 


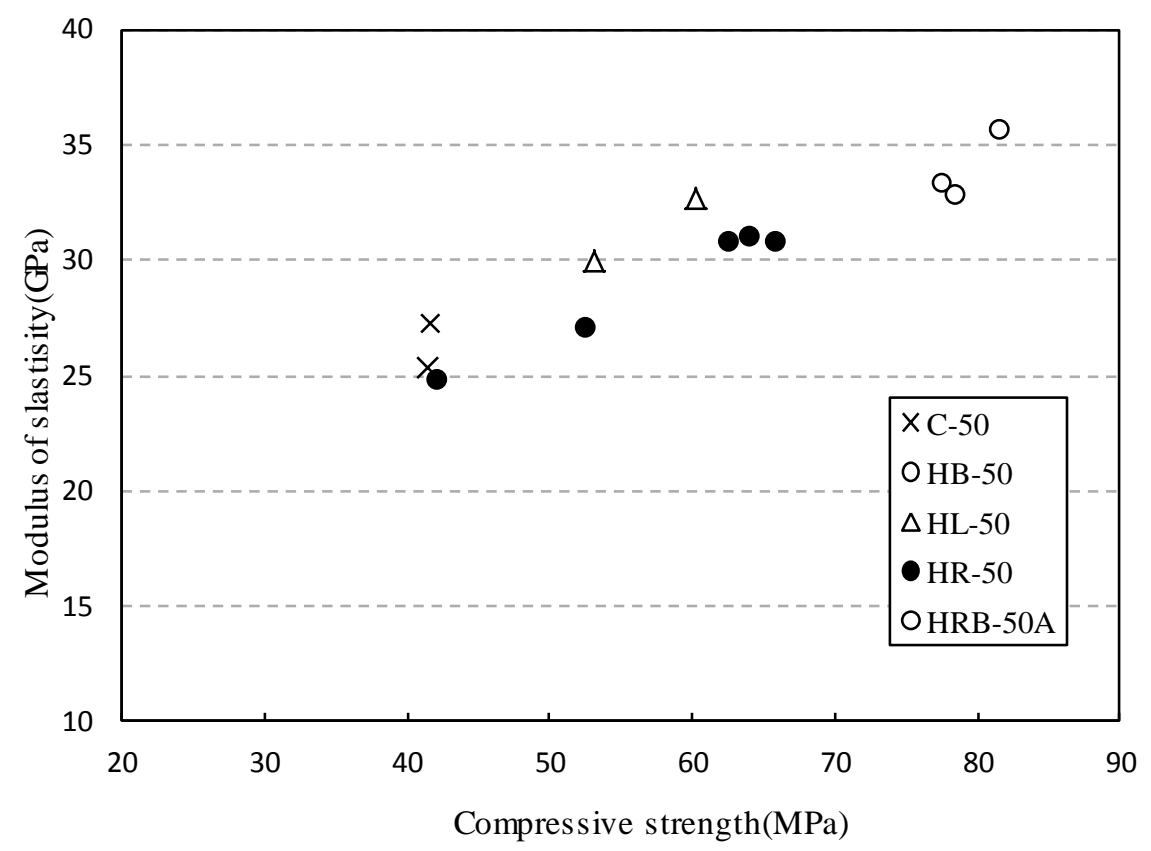

Fig. (5). Relationship between compressive strength and modulus of elasticity.

Drying shrinkage was greater for concrete with recycled fine powder than those with ground slag and ground limestone as shown in Fig. (6). Increase in drying shrinkage of concrete with recycled fine powder can be due to the pore structure in concrete [23]. The addition of ground slag together with recycled fine powder reduced shrinkage of concrete with recycled fine powder.

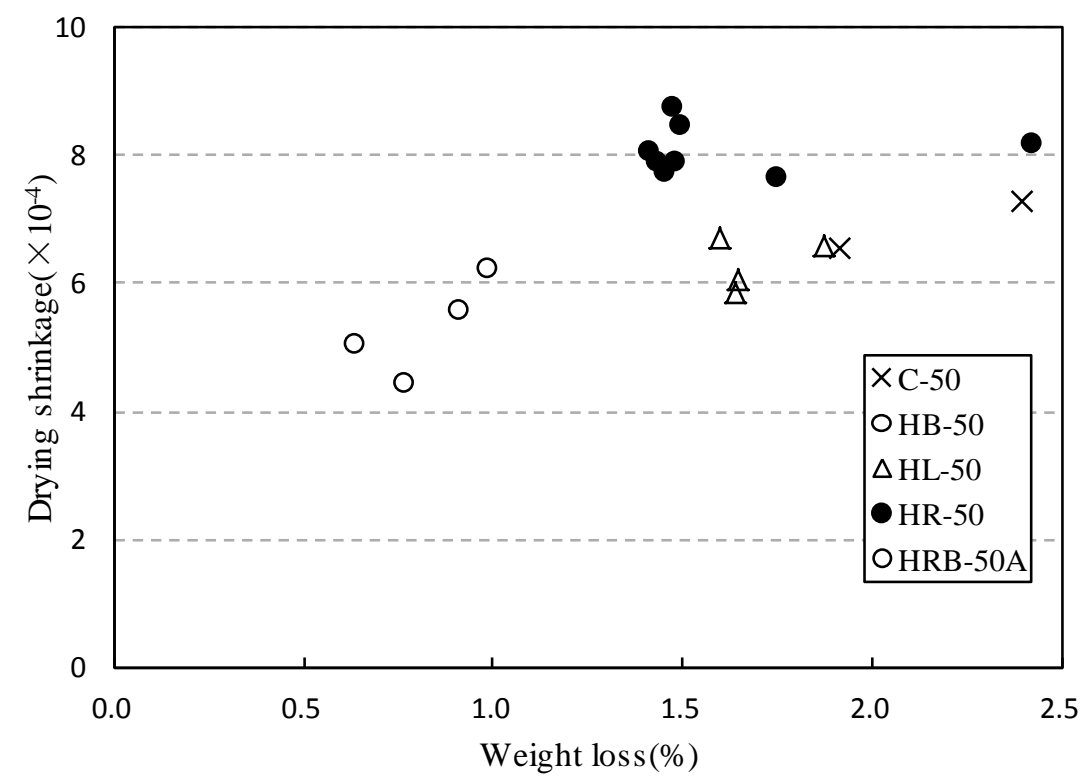

Fig. (6). Variation of the drying shrinkage with weight loss.

\subsection{Influence of Recycled Fine Powder}

Dosage of high range water reducer was increased with the addition of recycled fine powder, being three limes as much as those with slag and limestone as shown in Fig. (3). Reduction in super plasticizing effect of high range water reducer with the addition of recycled fine powder can be due to its angular particle shape or higher adsorption of high range water reducer. Increase in dosage of rather expensive high range water reducer would reduce the cost benefit of using recycled fine powder. 
Addition of recycled fine powder was found to increase compressive strength as much as ground limestone. Selfcompacting concrete with a W/CM of 0.50 containing $160 \mathrm{~kg} / \mathrm{m} 3$ of recycled fine powder could reach a strength of 65 $\mathrm{MPa}$ at 28 days. Increase in compressive strength with the addition of recycled fine powder can be due to its filler effect and hydration of unhydrated cement particles. Recycled fine powder does not affect the relationship between compressive strength and splitting tensile strength, as shown in (Fig. 7).

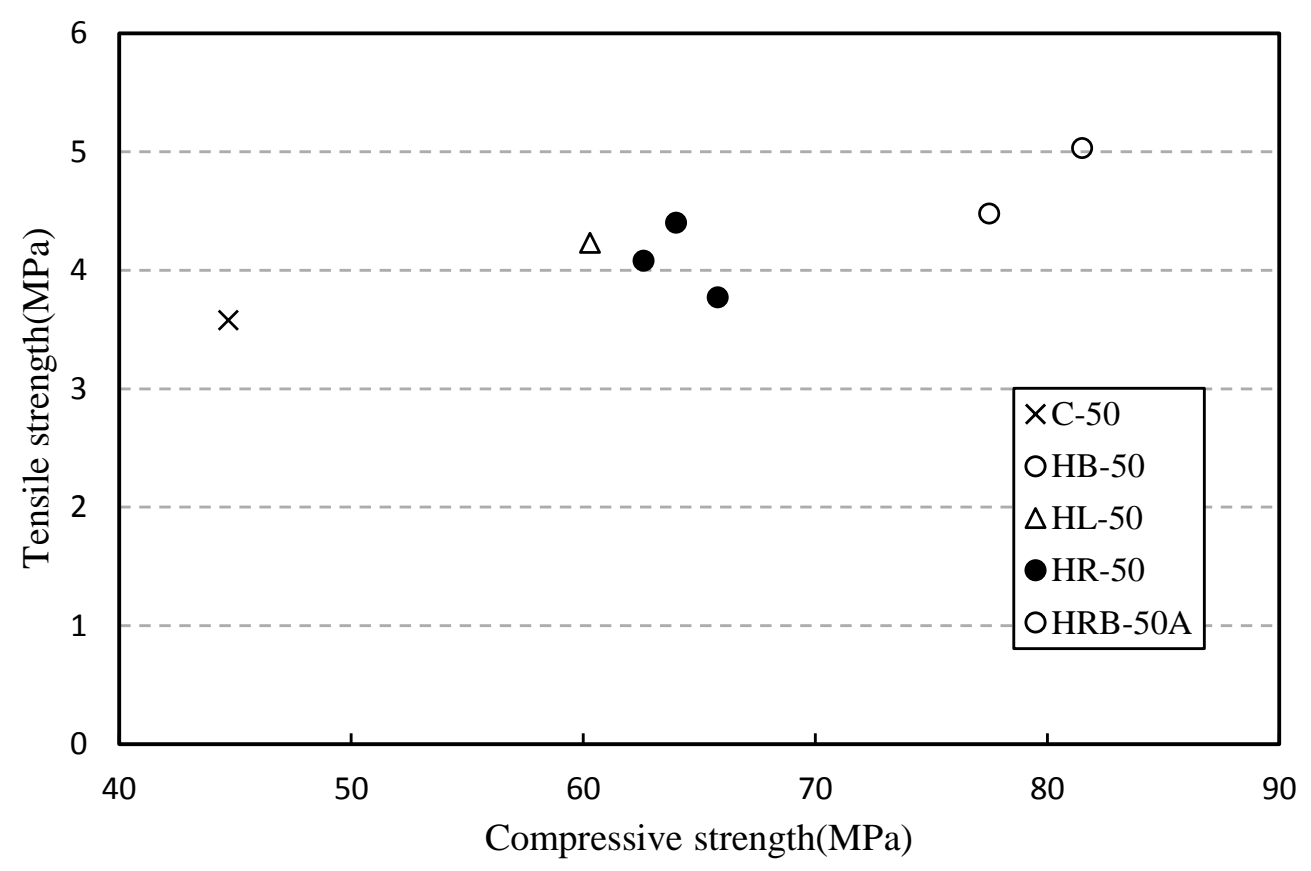

Fig. (7). Relationship between compressive strength and splitting tensile strength.

Modulus of elasticity of concrete with recycled fine powder is lower than those of the same strength concrete with ground slag and limestone. Relationship between compressive strength and modulus of elasticity of self-compacting concrete with ground slag, ground limestone and recycled fine powder are shown in Fig. (5).

The most negative influence of recycled fine powder is the increase in drying shrinkage. Fig. (6) shows the relationship between drying shrinkage and weight loss. Increase in drying shrinkage can be due to drying shrinkage of hydrated cement particles and reduction in modulus of elasticity.

\subsection{Possibility of Utilization of Recycled Fine Powder}

Recycled fine powder, by-product of high quality recycled aggregate by heating grinding method, is applicable for mineral additives to produce self-compacting concrete without further processing, despite possible increase in dosage of high range water reducer and in drying shrinkage.

The utilization of recycled fine powder as mineral additives for self-compacting concrete is significant for the practical application of recycled aggregate by heating grinding method, and correspondingly for the preservation of environment.

\section{CONCLUSION}

The following conclusions were drawn from the work presented above on the effects of by-product recycled fine powder on properties of self-compacting concrete.

1. By-product recycled fine powder obtained heating and grinding method to produce high quality recycled aggregate consists of fine particles of crushed aggregate and hydrated cement and had specific surface area of $330 \mathrm{~m} 2 / \mathrm{kg}$ to $530 \mathrm{~m} 2 / \mathrm{kg}$.

2. Addition of recycled fine powder causes reduction in super plasticizing effect of high range water reducer.

3. Self-compacting concrete containing recycled fine powder had the same compressive strength as those with 
ground lime stone, and had lower modulus of elasticity and larger drying shrinkage than those with ground lime stone and ground slag.

4. Recycled fine powder can be used as mineral additives to produce self-compacting concrete without further processing, despite possible increase in dosage of high range water reducer and in drying shrinkage.

5. Addition of ground blast furnace slag together with recycled fine powder improves super plasticizing effect of high range water reducer as well as qualities of self-compacting concrete containing recycled fine powder.

\section{CONSENT FOR PUBLICATION}

Not applicable.

\section{CONFLICT OF INTEREST}

The authors declare no conflict of interest, financial or otherwise.

\section{ACKNOWLEDGEMENTS}

Financial support from the Shandong Natural Science Foundation (Grant No. ZR2016GM06) is gratefully acknowledged.

\section{REFERENCES}

[1] J. Liu, and C. Wu, "Development status and performance research of recycled concrete", Concrete (Lond.), vol. 6, pp. 148-150, 2018.

[2] J. Chen, "Current status and suggestions on the utilization of construction waste resources in china", Constr. Sci. Technol., vol. 1, pp. 8-12, 2014.

[3] H. Quan, H. Kasami, and T. Tamai, "Experimental study on effects of adhered mortar content on quality of recycled coarse aggregate and properties of concrete", Proceedings of the 2nd International Conference on Waste Engineering and Management, pp. 491-500, 2010.

[4] W.Y. Vivian, C. M Tam, and K. N. Le, "Removal of cement mortar remains from recycled aggregate using pre-soaking approaches", Resour. Conserv. Recycling, vol. 50, no. 1, pp. 82-101, 2007.

[http://dx.doi.org/10.1016/j.resconrec.2006.05.012]

[5] H. Watanabe, H. Kasami, M. Abe, and S. Shimura, "Experimental study on the effects of quality recycled coarse aggregate on the strength and durability of concrete", Transaction of Annual Meeting of Architectural Institute of Japan A, pp. 241-242, 2003.

[6] H. Quan, and H. Kasami, "Study on properties of self-compacting concrete with recycled powder", Adv. Mat. Res., vol. 250-253, pp. 866-869, 2011.

[7] H. Kasami, M. Hosino, T. Arasima, and H. Tateyasiki, "Use of recycled concrete powder in self-compacting concrete", ACI International Concrete Abstracts Portal, vol. 200, pp. 381-398, 2001.

[8] H. Tateyashiki, H. Shima, Y. Matsumoto, and Y. Koga, "Properties of concrete with high quality recycled aggregate by heat and rubbing method", Proceedings of Japan Concrete Institute, Japan, vol. 23, no. 2, pp. 61-66.

[9] H. Shima, H. Tateyashiki, R. Matsuhashi, and Y. Yoshida, "Life cycle analysis of high quality recycled aggregate produced by heating and rubbing method", In: IEEJ Transactions on Electronics Information \& Systems, 2003, pp. 1680-1687.

[10] M. Tsujino, T. Noguchi, M. Tamura, M. Kanematsu, and I. Maruyama, "Application of conventionally recycled coarse aggregate to concrete structure by surface modification treatment", J. Adv. Concr. Technol., vol. 5, no. 1, pp. 13-25, 2007. [http://dx.doi.org/10.3151/jact.5.13]

[11] Y. Dosho, "Development of a sustainable concrete waste recycling system (Application of recycled aggregate concrete produced by aggregate replacing method)", J. Adv. Concr. Technol., vol. 5, no. 1, pp. 27-42, 2007.

[http://dx.doi.org/10.3151/jact.5.27]

[12] H. Shima, H. Tateyashiki, R. Matsuhashi, and Y. Yoshida, "An advanced concrete recycling technology and its applicability assessment through Input-output analysis", J. Adv. Concr. Technol., vol. 3, no. 1, pp. 53-67, 2005.

[http://dx.doi.org/10.3151/jact.3.53]

[13] A. Iizuka, M. Nakagawa, K. Kumagai, A. Yamasaki, and Y. Yanagisawa, "Chemical extraction and mechanical crushing method for fine aggregate recycling from waste concrete", J. Chem. Eng. of Jpn, vol. 43, no. 10, pp. 906-912, 2010. [http://dx.doi.org/10.1252/jcej.09we236]

[14] Y. Takemoto, H. Hashida, Y. Kuroda, N. Enomoto, T. Akatsu, and K. Tanaka, "Material separation of waste concrete fine powder", J. Struct. Constr. Eng. AIJ, vol. 73, no. 11, pp. 1891-1898, 2008.

[http://dx.doi.org/10.3130/aijs.73.1891]

[15] K. Bru, S. Touzé, F. Bourgeois, N. Lippiatt, and Y. Ménard, "Assessment of a microwave-assisted recycling process for the recover of high quality aggregate from concrete waste", Int. J. Miner. Process., vol. 126, no. 1, pp. 90-98, 2014. [http://dx.doi.org/10.1016/j.minpro.2013.11.009] 
[16] V. Spaeth, and A.D. Tegguer, "Improvement of recycled concrete aggregate properties by polymer treatments", Int. J. Sustainable Built Environ., vol. 2, no. 12, pp. 143-152, 2013. [http://dx.doi.org/10.1016/j.ijsbe.2014.03.003]

[17] J. Zhang, C. Shi, Y. Li, and Z. Xie, "Performance enhancement of recycled concrete aggregate through carbonation", J. Mater. Civ. Eng., vol. 27 , no. 11 , pp. 1-6, 2015. [http://dx.doi.org/10.1061/(ASCE)MT.1943-5533.0001296]

[18] C.S. Poon, Z.H. Shui, L. Lam, H. Fok, and S.C. Kou, "Influence of moisture states of natural and recycled aggregates on the slump and compressive strength of concrete", Cement Concr. Res., vol. 34, no. 1, pp. 31-36, 2004. [http://dx.doi.org/10.1016/S0008-8846(03)00186-8]

[19] H. Choi, M. Lim, H. Choi, R. Kitagaki, and T. Noguchi, "Using microwave heating to completely recycle concrete", J. Environ. Prot. (Irvine Calif.), vol. 5, no. 7, pp. 583-596, 2014. [http://dx.doi.org/10.4236/jep.2014.57060]

[20] H. Shima, H. Tateyashiki, R. Matsuhashi, and Y. Yoshida, "Life cycle analysis of high quality recycled aggregate with use of byproduct powder as soil stabilizer", Concr. Res. Technol., vol. 15, no. 1, pp. 81-91, 2004. [http://dx.doi.org/10.3151/crt1990.15.1_81]

[21] Ö. Çakır, "Experimental analysis of properties of Recycled Coarse Aggregate (RCA) concrete with mineral additives", Constr. Build. Mater., vol. 68 , no. 3, pp. 17-25, 2014.

[http://dx.doi.org/10.1016/j.conbuildmat.2014.06.032]

[22] Y. Li, and J. Li, "Relationship between fracture area and tensile strength of cement paste with supplementary cementitious materials", Constr. Build. Mater., vol. 79, pp. 223-228, 2015.

[http://dx.doi.org/10.1016/j.conbuildmat.2015.01.052]

[23] Y. Li, and J. Li, "Capillary tension theory for prediction of early autogenous shrinkage of self-consolidating concrete", Constr. Build. Mater., vol. 53, no. 3, pp. 511-516, 2014.

[http://dx.doi.org/10.1016/j.conbuildmat.2013.12.010]

(C) 2018 Quan and Kasami.

This is an open access article distributed under the terms of the Creative Commons Attribution 4.0 International Public License (CC-BY 4.0), a copy of which is available at: https://creativecommons.org/licenses/by/4.0/legalcode. This license permits unrestricted use, distribution, and reproduction in any medium, provided the original author and source are credited. 